\title{
TURKISH SECRETS HIDDEN IN OUR STREETS
}

\author{
Balázs KÓSA ${ }^{1}$, Hajnalka JUHÁSZ2 ${ }^{2}$, Lilla GYÜRE ${ }^{3}$, Olivér SCHMIDT ${ }^{4}$, \\ Renáta NÉMETH-SZIGETI ${ }^{5}$, Kinga PACZOLAI ${ }^{6}$, Attila Béla SZÉLL ${ }^{7}$ \\ University of Pécs, Faculty of Engineering and Information Technology, Pécs, Hungary \\ ${ }^{1-4}$ Department of Visual Studies, kosa.balazs@mik.pte.hu \\ ${ }^{5}$ Department of Engineering Studies, reni.szigeti@gmail.com \\ ${ }^{6}$ Department of Architecture and Urban Planning, paczolaik@gmail.com \\ ${ }^{7}$ Department of Building Structures and Energy Design, szellattila@mik.pte.hu
}

\begin{abstract}
Hungary has been the home of many peoples from the beginnings of its history. As a result, our accumulated heritage is made up of buildings which were built, used and formed by different peoples during their lifetimes. This study investigates the diversity of the built heritage, the architectural and social multiculturalism in the city centre of Pécs.
\end{abstract}

Keywords: Turkish, downtown, monumental building, Pécs, mosque.

\section{The Ottoman Empire in Hungary}

\subsection{Historical overview}

Thesis 1. Buildings and fortifications made by a conquering empire can also become defining elements of our national and local identity over time.

It can be observed in the history of architecture that the occupying powers often force their culture, and by this, their architectural culture upon the defeated countries and their population as a demonstration of power. As a result of this, houses, public baths and places of worship originating from the Turkish times - built to advertise oppression, and nowadays representing such priceless value without which our country would be poorer in architectural monuments - can (also) be found in many Hungarian towns.

A significant part of Hungary was conquered by the Turks in the 16th century in a remarkably short time and was made into an organic part of the Ottoman Empire. They introduced both their social and their economic views in the occupied areas, ensuring their power and the creation of unity. Therefore, Pécs abounds in Turkish monu- ments, in this respect it is one of our richest cities. Two mosques (Kasim Pasha's and Jakovali Hasan Pasha's) [1], and also Ferhád Pasha's mosque and the tanners' mosque, ruined or partially rebuilt', recalling the atmosphere of the Turkish times can be found here - mainly concentrated in the city centre.

\section{Mosques in Pécs}

Evlia Cselebi, the famous Turkish traveller wrote about 17 mosques at Pécs in his travelogue. [2] It is believed that these details are presumably authentic because we read almost the same number in the notes of Pál Esterházy. [3] In another description from the same year (1664), only 9 buildings were mentioned but probably the church at Kórház-square and the cathedral are omitted from this list. These two buildings are not mosques, but at that time they were used as religious places of the temporary conquering empire. In conclusion, the real number of the mosques could be 11. A map made by Joseph de Haüy shows the same facts. [4] The artificer officer also refers to 9 mosques and from these build- 
ings 5 are clearly named mosque. The other 4 are referred to as the place of prayer's but from the orientation of the buildings (in the direction of Mecca) we can presume that they were mosques too. By the strategist, the church of the Franciscans and the cathedral were already registered as Christian monuments. To sum up, from these previous records we can conclude that Evlia Cselebi and Pál Esterházy noted the real number of the mosques.

In our research, not in much detail Gazi Kasim Pasha, Jakovali Hasan Pasha, Memi Pasha, El-Hadzsi Husejn, Sulejman-chatedral, and the tanner's mosque) we investigate the history and the utilization of Jakovali Hasan Pasha's mosque. The analyzation of Gazi Kasim Pasha's building (which was presumably formed in 1580 [5]) will be included in another study.

\section{Solutions, Plans}

Thesis 2. It is not enough to work on the conservation documentation of the monument itself, the investigation, supervision and reutilization of the environment surrounding it is also necessary.

Many Hungarian cities abound in buildings, ruins of historical significance, but merely docketing them as monuments in the archives and conserving and recording their present condition is not sufficient. During the reconstructions and the geometric surveying, it is worth starting the reconstruction from a little distance. It is necessary to think within the given plot, but the district, the street, the block also needs to be considered in the investigation.

In this way, we have discovered more ideas. From these we will present the installation which was created to the Jakovali Hasan Pasha's mosque. During the planning process some of the main issues were the low budget and the fact that we didn't want to make huge meddling at the surrounding area. Additionally it is necessary to share some thoughts about the building.

Nowadays Jakovali Hasan Pasha's mosque is situated in a really busy part of Pécs. Accordingly this location, and also the position of the mosque (which shows that it is wedged between to the neighbouring buildings) means that this valuable Turkish monument is barely noticed by most people. It was probably built in the second part of $16^{\text {th }}$ century and after recapture of the city the mosque functioned as a chapel. Although thet interior was redesigned (by Nesselrode bishop) the building has almost entirely all the original Turk- ish details. The building was made of stone and partly brick, with a quadratic layout covered by a 13x13 metre octagonal based dome. This dome was mentioned as having a blue tin cover by Evlia Cselebi. On the first level the ogee arch windows (originally made by Turkish bricks and painted red and white stripes) were finished as a transom-window. These are faced with stone-framed and circularly-perforated concrete windows. In former times there were stucco-framed windows behind them but today just concrete-framed ones remain (like the sample of Gazi Kasim Pasha's mosque). On the second level the windows have already been finished with semi-circular arches. The building displays a multiply divided ledge under the dome which initially was also coloured red and white. The entrance is a multiply divided stone-frame again and this structure includes the kitábe (wall painting which notes the year the mosque was built). Unfortunately this painting has become ruined over time. The remains of the avlu (courtyard) were discovered in the basement of the present hospital. The traditional prayer-carpets were placed on the floor which was made by limestone from the Mecsek- mountains. Facing the entrance (on the south-eastern side of the mosque) a twelve-angled niche is seen which is called mihráb and shows the direction of Mecca. It is covered with stalactite-vaultage and decorated with the tugra (Pasha's painted signature). The minber (pulpit) stands on the right side of the tugra and on the left side the kürszi (preacher's podium) was originally placed (it is not standing today). From the remains of the beams we can conclude that the building had a mahfil (gallery) where the müezzin (person appointed at the mosque) and the nobles prayed. The minaret (the thin tower where the müezzin called the people to prayer five times a day) is connected to the building's right side.

As mentioned before, the building is barely observable from its location. That was the main point that we wanted to solve with our installation, with an informational board. By our observation the board was installed on two different and significant points of the Kórház-square. One of them was placed in the direction of the pedestrian street and the other was placed near to the southern bus stop. The first one on the crowded pedestrian street could open people's eyes to the Turkish building both including those who have long known the area well. Our goal was to present the mosque in a special way, but without causing damage to the surroundings. The solution that we 
have created and described like a picture-frame artwork was a specific board. We cut it of segments, firstly just smaller parts, but after the whole mosque's silhouette. The final picture covered out the direct environment of the building and along with this put on focus to the Turkish monument.

\section{Findings, summary}

We believe that preserving and regenerating our built heritage is one of the most important tasks of architecture today. From the already existing solutions, we have chosen one which is based on analysis of the surrounding environment and which also produces less interference than the others methods.

Our further objective is to investigate these buildings considering which SMART technologies could possibly be used during our projects. We would like to concentrate particularly on virtual reality, the VR technology, using it for presentation. The surveying was already made in the spirit of this experimenting because we compared the man-made surveying with the surveying made by a drone. Although faster, but the drone could reconstruct the floor plan contour of the building less precisely ( $5 \mathrm{~cm}$ precisely) based on the photos. However, it is able to build a 3D model with the help of a converter programme within a relatively short time.

On hearing about VR technologies, most people associate it directly with architecture, and in this case we would like to exploit this. A presentational tool is in our hands which makes it possible for the people with little sight of space or with none at all to imagine how the building looked or will look like.

Thus, beyond surveying, we will try to visualize and help the future of the buildings.
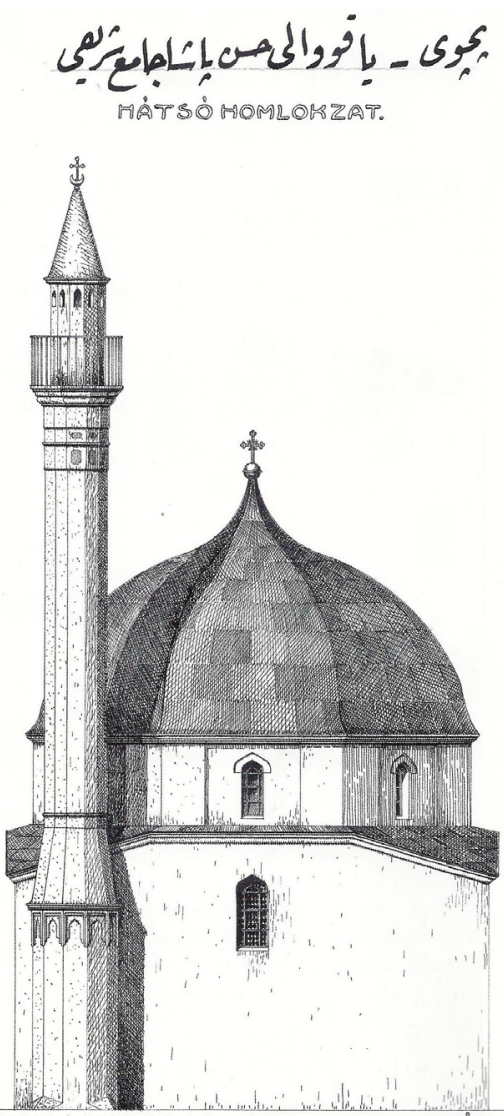

MAKOUALU MASSAN P ASCHA DSAMUA PECSETT.
MOSSZMETSET.

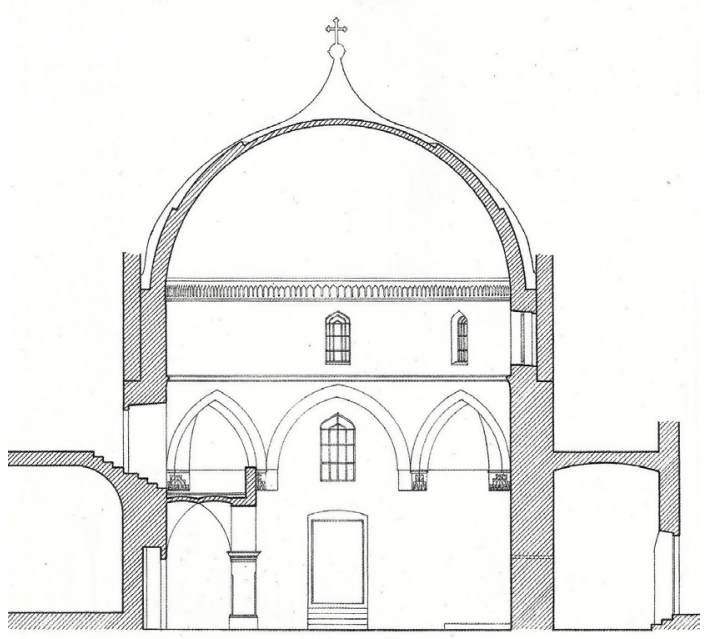

马RLSO゚ RESLETEK.
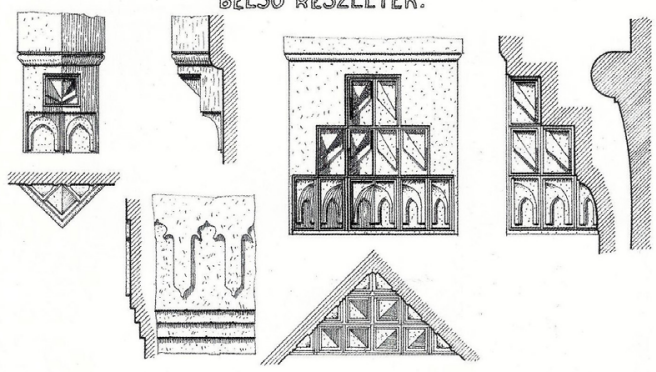

$\mathbb{B}_{0}^{\text {aig }}$

Figure 1. The elevation and the section of the mosque, surveying of Ernö Foerk, 1917. [7] 


\section{References}

[1] Madas J.: Az elpusztult pécsi mecsetek. Pécsi Műszaki Szemle 18/2-3. (1973) 41-47.

[2] Evliya Çelebi b. Derviş Mehemmed Zillî: Evliyâ Çelebi Seyahatnâmesi. Topkapı Sarayı Kütüphanesi Revan 1457 Numaralı Yazmanın Transkripsiyonu - Dizini. 6. Kitap. Haz. Seyyid Ali Kahraman-Yücel Dağll. Yapı Kredi Yayınları, İstanbul, 2002. 114-116.; Evlia Cselebi török világutazó magyarországi utazásai. Ford.: Karácson Imre. Gondolat, Budapest, 1985. 228-231.
[3] Esterházy P.: Mars Hungaricus. Zrínyi Kiadó, Budapest, 1989. 142.

[4] Kisari Balla Gy.: Karlsruhei térképek a török háborúk korából. Magánkiadás, Budapest, 2000. 344.

[5] Kiss A.: A pécsi belvárosi templom története. Pécs, 1906. 7.

[6] Gosztonyi Gy.: A várostemplom építéstörténete. Pécs Belvárosi Római Kath. Egyházközség, Pécs, 1942. 5-6.

[7] Sudár B.: A pécsi Jakováli Haszan Pasa-dzsámi. Müemlékek Nemzeti Gondnoksága, Budapest, 2010. 80, 81 . 